\title{
Chronic ectopic pregnancy complicated by septicemic shock and disseminated intravascular coagulation
}

\author{
Mamta Sharma, Rajkumar* \\ Department of Obstetrics and Gynecology, Government Medical College, Kota, Rajasthan, India
}

Received: 26 October 2021

Revised: 29 November 2021

Accepted: 02 December 2021

\author{
*Correspondence: \\ Dr. Rajkumar, \\ E-mail: rajkumar020994@rediffmail.com
}

Copyright: ( ) the author(s), publisher and licensee Medip Academy. This is an open-access article distributed under the terms of the Creative Commons Attribution Non-Commercial License, which permits unrestricted non-commercial

\begin{abstract}
Disseminated intravascular coagulation is a life threatening complication of ectopic pregnancy. It results from washing out of all important procoagulants. This is basically a state of increased propensity for clot formation triggered by a variety of stimuli related to such diverse disorders as sepsis, endothelial cell damage (heat stroke and shock), obstetrical complication (abruptio placenta, amniotic fluid embolism, severe preeclampsia and retained intrauterine dead foetus). A case of disseminated intravascular coagulation with septicemic shock following laprotomy for ectopic pregnancy is reported. She was treated by vasopressors, broad spectrum antibiotic and aggressive blood and blood component therapy.
\end{abstract}

Keywords: Disseminated intravascular coagulation, DIC

\section{INTRODUCTION}

Ectopic pregnancy occurs in $1.5 \%$ to $2 \%$ of all pregnancies associated mortality has decreased to 0.5 death per 1000 pregnancies. However despite advancements in treatment, ruptured ectopic pregnancies are third leading cause of maternal deaths. ${ }^{1}$ Disseminated intravascular coagulation (DIC) is a clinical syndrome characterized by systemic activation of coagulation cascade simultaneously leads to intravascular thrombus formation (compromising blood supply to various organs) and exhaustion of platelets and coagulation factors (resulting in hemorrhage). DIC is uncommon but not rare. The incidence of the syndrome varies in association with different disorders. In obstetrical conditions, such as abruptio placenta and amniotic fluid embolism, DIC occurring in more than $50 \%$ of cases. DIC may be classified according to its acuteness and clinical severity; acute DIC, sub-acute DIC or chronic DIC. Obstetrical causes of DIC can be classified as acute and chronic. DIC may be the result of single or multiple conditions. Acute DIC in placental abruption, amniotic fluid embolism, severe preeclampsia or eclampsia, obstetric sepsis, septic abortion or saline abortion, acute fatty liver of pregnancy, extensive surgical trauma, massive blood transfusion. sub-acute or chronic DIC in retained dead fetus syndrome, retained products of conception degenerating hydatidiform moles, abdominal (ectopic) pregnancy, saline induced abortion, fetomaternal blood passage, postpartum haemolyticureamic. ${ }^{2}$

\section{CASE REPORT}

A 21 year old female with para 2 and live 2 and 1 ectopic (P2L2E1) presented in an emergency with poor general condition, temp afebrile, pulse 130 per minute, blood pressure (BP) 80/40, respiratory rate 22/minute, $\mathrm{SPO}_{2}$ $94 \%$, pallor+, S1 and S2 normal, bilateral chest clear, per abdomen soft, and per vaginal examination uterus was normal size. She was referred from private hospital for hypotension and oliguria after laprotomy with history of 2 month amenorrhea followed by pain abdomen, bleeding per vagina and vomiting. On her preoperative trans vaginal ultrasonography (USG) right adenexal mass possible ectopic pregnancy (collapsed sac with increased trophoblastic vascularity (ring of fire+) medial to right ovary and hemoperitonium. Urine pregnancy test was 
positive .her private hospital operative notes showed laperotomy for ruptured ectopic and massive hemoperitonium and right partial salpigectomy 24 hours ago.one unit PCV transfusion was done. Patients urine output was $1200 \mathrm{cc}$ slight hemorrhagic after 12 hours of laprotomy. Patient developed headache and nausea after 15 hours of laprotomy. Postoperative, hemoglobin $(\mathrm{Hb})$ was $13 \mathrm{gm} \%$, platelet 30000, white blood cells (WBC) count 13200, prothrombin time (PT) $23 \mathrm{sec}$, international normalized ratio (INR) 2.26, serum glutamate oxaloacetate transferase (SGOT) 56.93, serum glutamic pyruvic transaminase (SGPT) 38.92, serum thyroid stimulating hormone (TSH) 1.82, serum bilirubin 2.1 .
All necessary investigations were done. Patient was diagnosed DIC with septicemic shock following laprotomy for right tubal ectopic. She was put on noradrenaline infusion. Patient was managed conservatively with IV fluid, broad spectrum antibiotics and 19 units fresh frozen plasma (FFP); 7 units random donor platelets (RDP), 3 units single donor platelets (SDP), and one unit whole blood transfusion. Patient improved on conservative management and vasopressor (noradrenaline) was stopped on day 10 and patient discharged on day 15 but did not come for follow up with histopathological report. Important investigations and treatment are given in Table 1.

Table 1: Post-operative investigation and treatment.

\begin{tabular}{|c|c|c|c|c|c|c|}
\hline Date & $\mathrm{CBC}$ & LFT & RFT & $\begin{array}{l}\text { Coagulation } \\
\text { profile }\end{array}$ & $\begin{array}{l}\text { Serum } \\
\text { electrolyte }\end{array}$ & Treatment given \\
\hline Day 1 & $\begin{array}{l}\mathrm{Hb}-8.8 \text { gm } \%, \\
\text { WBC-14450 } \\
\text { Platelet-12000 }\end{array}$ & $\begin{array}{l}\text { S. bilirubin-2.3 } \\
\text { mg\% } \\
\text { SGOT-97 IU/1 } \\
\text { SGPT-76I U/1 } \\
\text { S. LDH-1057 } \\
\text { IU/1 }\end{array}$ & $\begin{array}{l}\text { Blood urea- } \\
51 \mathrm{mg} / \mathrm{dl} ; \mathrm{S} \text {. } \\
\text { creatinine- } \\
1.6 \mathrm{mg} / \mathrm{dl}\end{array}$ & $\begin{array}{l}\text { PT-control } 13.5 \\
\text { sec; test; } 31.4 \\
\text { sec; INR-2.39 }\end{array}$ & $\begin{array}{l}\mathrm{Na}^{+}-136 \\
\mathrm{~K}^{+}-2.9 \\
\mathrm{Cl}^{-}-103\end{array}$ & $\begin{array}{l}1 \text { unit PCV, } 4 \text { unit } \\
\text { RDP, } 1 \text { unit SDP, } 8 \\
\text { unit FFP; antibiotics; } \\
\text { and all supportive and } \\
\text { symptomatic treatment } \\
\text { given }\end{array}$ \\
\hline Day 2 & $\begin{array}{l}\mathrm{Hb}-9.4 \text { gm\% } \\
\text { WBC-24540 } \\
\text { Platlets-26000 }\end{array}$ & $\begin{array}{l}\text { S. bilirubin-2.1 } \\
\text { mg\% } \\
\text { SGOT-147 IU/L } \\
\text { SGPT-120 IU/L } \\
\text { S. LDH-1089 } \\
\text { IU/L }\end{array}$ & $\begin{array}{l}\text { Blood urea- } \\
54 \mathrm{mg} / \mathrm{dl} ; \mathrm{S} \text {. } \\
\text { creatinine- } \\
4 \mathrm{mg} / \mathrm{dl}\end{array}$ & $\begin{array}{l}\text { PT-control } 16.5 \\
\text { sec; test } 28.4 \\
\text { sec; INR-2.15 }\end{array}$ & $\begin{array}{l}\mathrm{Na}^{+}-141 \\
\mathrm{~K}^{+}-3.4 \\
\mathrm{Cl}^{-}-104\end{array}$ & $\begin{array}{l}4 \text { unit RDP, } 4 \text { unit FFP; } \\
\text { antibiotics; and all } \\
\text { supportive and } \\
\text { symptomatic treatment } \\
\text { given }\end{array}$ \\
\hline Day 3 & $\begin{array}{l}\mathrm{Hb}-8.1 \text { gm\% } \\
\text { WBC-39960 } \\
\text { Platlets-18000 }\end{array}$ & $\begin{array}{l}\text { S. bilirubin - } \\
3.2 \mathrm{mg} \% \\
\text { SGOT-337 IU/1 } \\
\text { SGPT-223 IU/1 }\end{array}$ & $\begin{array}{l}\text { Blood urea- } \\
46 \mathrm{mg} / \mathrm{dl} ; \mathrm{S} \text {. } \\
\text { creatinine- } \\
1.5 \mathrm{mg} / \mathrm{dl}\end{array}$ & $\begin{array}{l}\text { PT-control } 13.5 \\
\text { sec; test } 26.4 ; \\
\text { INR-1.99; FDP- } \\
9.60 \mathrm{ug} / \mathrm{ml} ; \mathrm{D} \\
\text { dimer } 2580 \\
\text { ng/ml; } \\
\text { APTT/PTTK } \\
\text { time } 60 \mathrm{sec} ; \\
\text { APTT/PTTK } 34 \\
\text { sec }\end{array}$ & $\begin{array}{l}\mathrm{Na}^{+}-140 \\
\mathrm{~K}^{+}-2.8 \\
\mathrm{Cl}^{-}-103\end{array}$ & $\begin{array}{l}1 \text { unit SDP, } 4 \text { unit FFP; } \\
\text { antibiotics; all } \\
\text { supportive and } \\
\text { symptomatic treatment } \\
\text { given }\end{array}$ \\
\hline Day 4 & $\begin{array}{l}\mathrm{Hb}-8.0 \mathrm{gm} \% \\
\text { WBC-32920 } \\
\text { Platlets-13000 }\end{array}$ & $\begin{array}{l}\text { S. bilirubin-2.4 } \\
\text { mg\% } \\
\text { SGOT-751 IU/1 } \\
\text { SGPT-575 IU/1 }\end{array}$ & $\begin{array}{l}\text { Blood urea- } \\
89 \mathrm{mg} / \mathrm{dl} ; \mathrm{S} \text {. } \\
\text { creatinine- } \\
1.8 \mathrm{mg} / \mathrm{dl}\end{array}$ & $\begin{array}{l}\text { PT control } 13.5 \\
\text { sec; test-29.2 } \\
\text { sec; INR-2.21 }\end{array}$ & $\begin{array}{l}\mathrm{Na}^{+}-142 \\
\mathrm{~K}^{+}-2.6 \\
\mathrm{Cl}^{-}-106\end{array}$ & $\begin{array}{l}4 \text { unit FFP; antibiotics; } \\
\text { all supportive and } \\
\text { symptomatic treatment } \\
\text { given }\end{array}$ \\
\hline Day 5 & $\begin{array}{l}\text { HB-7.8 gm\% } \\
\text { WBC-18630 } \\
\text { Platlets-52000 }\end{array}$ & $\begin{array}{l}\text { S. bilirubin- } 1.8 \\
\text { mg\% } \\
\text { SGOT-61 IU/1 } \\
\text { SGPT-710 IU/1 }\end{array}$ & $\begin{array}{l}\text { Blood urea- } \\
70 \mathrm{mg} / \mathrm{dl} ; \mathrm{S} \text {. } \\
\text { creatinine- } \\
1.3 \mathrm{mg} / \mathrm{dl}\end{array}$ & $\begin{array}{l}\text { PT-control } \\
13.5 \mathrm{sec} ; \text { test } \\
32.3 ; \text { INR-2.45; } \\
\text { FDP-8.65 ug/ml }\end{array}$ & $\begin{array}{l}\mathrm{Na}^{+}-140 \\
\mathrm{~K}^{+}-3.0 \\
\mathrm{Cl}^{-}-100\end{array}$ & $\begin{array}{l}\text { Antibiotics; all } \\
\text { supportive and } \\
\text { symptomatic treatment } \\
\text { given }\end{array}$ \\
\hline
\end{tabular}

\section{DISCUSSION}

Tubal ectopic pregnancy presents as an acute or chronic illness, or occasionally acute or chronic. The chronic presentation is more common, but the acute picture is so dramatic that it tends to receive more attention. Chronic DIC has been described in most patients with intrauterine foetal death. DIC is usually associated with infections, the commonest cause, about $10-20 \%$ of patients with gram negative sepsis have evidence of DIC. chronic ectopic pregnancy, Cole and Corlett et al 1982 reported a large number of complications, but none of their series of 50 cases developed DIC. ${ }^{3}$ Indeed, the only previous association between ectopic pregnancy and DIC that could be found was that reported by Patrinellis et al 1983 in whose patient the rupture of a tubal pregnancy was followed by massive intraperitoneal haemorrhage, with hypotension and hypovolaemia and the late onset of DIC following massive blood transfusion. ${ }^{4}$ Some of the clinical situations in obstetrics and gynaecology where DIC has been described. In the majority of these conditions, a 
"thromboplastic" material or thromboplastin precursor would appear to enter the maternal circulation, often leading to initial hypotension and collapse. This may later be associated with the development of DIC and substantial haemorrhage, with further deterioration of the patient's condition. Acute DIC only results when the normal compensatory mechanisms of haemostasis have been overcome. Direct platelet activation in septicemia and viraemic states; platelet activation will also result from vessel wall endothelial damage and following thrombin generation by the coagulation cascade. A combination of coagulation factor deficiency, thrombocytopenia, impaired platelet function, and inhibitory action of raised FDPS, causes the generalized and continuing widespread bleeding tendency. Chronic or "compensated" DIC result from a weak or intermittent activating stimulus. The exposure of procoagulent tissue extracts to blood is a major contributory factor in most forms of DIC. DIC often accompanies septicemia (mainly due to Gram-negative) as a result of septic abortion, bacteria that possess potent endotoxins. DIC involved in all forms of shock and that it is the central feature in irreversible or refractory forms. CB collier et al 1983 described risk of sudden collapse and development of DIC in the patient with chronic ectopic gestation, following pelvic examination. Rapid intravenous therapy and surgical intervention are required. ${ }^{5}$

\section{CONCLUSION}

This case presents a challenging diagnosis of DIC following laparotomy for rupture ectopic pregnancy. Only one case has been reported in literature. Early diagnosis of
DIC and its timely management is important to prevent further complication.

Funding: No funding sources

Conflict of interest: None declared

Ethical approval: Not required

\section{REFERENCES}

1. Chang J, Elam-Evans LD, Berg CJ, Herndon J, Flowers L, Seed KA, Syverson CJ. Pregnancy-related mortality surveillance--United States, 1991--1999. MMWR Surveill Summ. 2003;52(2):1-8.

2. Sultana S, Begum A, Khan M. Disseminated Intravascular Coagulation (DIC) in Obstetric Practice. J Dhaka Med Coll. 2011;20(1):68-74.

3. Cole T, Corlett RC Jr. Chronic ectopic pregnancy. Obstet Gynecol. 1982;59(1):63-8.

4. Patrinellis G. Disseminated intravascular coagulation with operated ectopic pregnancy. Acta Anaesth Hell. 1978;8:161-6.

5. Collier CB, Birrell WR. Chronic ectopic pregnancy complicated by shock and disseminated intravascular coagulation. Anaesth Intens Care. 1983;11(3):246-8.

Cite this article as: Sharma M, Rajkumar. Chronic ectopic pregnancy complicated by septicemic shock and disseminated intravascular coagulation. Int $\mathbf{J}$ Reprod Contracept Obstet Gynecol 2022;11:281-3. 